\title{
Enhancing the regeneration of compacted forest soils by planting black alder in skid lane tracks
}

\section{Journal Article}

Author(s):

Meyer, Christine; Lüscher, Peter; Schulin, Rainer

Publication date:

2014

Permanent link:

https://doi.org/10.3929/ethz-b-000082830

Rights / license:

In Copyright - Non-Commercial Use Permitted

Originally published in:

European Journal of Forest Research 133(3), https://doi.org/10.1007/s10342-013-0776-0 


\title{
Enhancing the regeneration of compacted forest soils by planting black alder in skid lane tracks
}

\author{
Christine Meyer $\cdot$ Peter Lüscher $\cdot$ Rainer Schulin
}

Received: 7 June 2013/Revised: 25 November 2013/Accepted: 17 December 2013/Published online: 25 December 2013

(C) Springer-Verlag Berlin Heidelberg 2013

\begin{abstract}
Soil compaction due to the use of heavy machinery for timber harvesting has become a widespread problem in forestry. However, only few studies deal with the regeneration of compacted forest soils. In the present study, we examined the potential of accelerating soil regeneration by planting black alder trees (Alnus glutinosa (L.) Gaertn.) in skid lane tracks. In 2003, seedlings were planted into the rut beds of severely compacted skid lanes in two Swiss forest sites. In addition, some of the ruts were filled with compost. In 2009 and 2010, we assessed the success of these measures by analysing physical parameters of soil structure (bulk density, total and coarse porosity and air permeability), root densities and tree growth. Tree growth was exceptionally strong on the skid lanes. Total and coarse soil porosity and air permeability showed significant increase in planted skid lanes as compared to untreated control subplots, approaching values found for untrafficked soil in the immediate vicinity. All soil physical parameters were closely correlated to root mass density. Compost application enhanced tree growth and soil structure regeneration on one site, but had a retarding effect on the other site. Planting black alders has great potential as an environmentally friendly measure to accelerate the structural regeneration of compacted forest soils in temperate humid climates.
\end{abstract}

Communicated by A. Merino.

C. Meyer $(\varangle) \cdot$ P. Lüscher

Swiss Federal Institute for Forest, Snow and Landscape Research (WSL), Zürcherstrasse 111, 8903 Birmensdorf, Switzerland e-mail: christine.meyer@wsl.ch

C. Meyer $\cdot$ R. Schulin

Institute of Terrestrial Ecosystems, ETH Zurich,

Universitaetstrasse 16, 8092 Zurich, Switzerland
Keywords Soil compaction - Soil structure regeneration · Forest soil - Black alder - Root growth

\section{Introduction}

Soil compaction is not only a major problem in intensive agriculture (Hamza and Anderson 2005; Soane and Van Ouwerkerk 1994), but is also becoming more and more an issue in forestry (Greacen and Sands 1980; Schäffer et al. 2012) due to increasing use of heavier timber harvesting machines with little regard for soil conditions (Apel 2001; Hameberger 2003). In the northern hemisphere, timber harvesting was traditionally performed during winter, when soils were frozen and labour was available from farms. Nowadays, economic pressure forces foresters to harvest all year round (Franz 2010; Ingold and Zimmermann 2011). Operating heavy timber machinery under wet conditions, when soils are particularly susceptible to compaction, has become a frequent cause of severe soil compaction, damaging forest productivity (Batey 2009; Hildebrand 1983; Whalley et al. 1995). In Switzerland, the most productive forests are in the lowlands and prealpine areas of the Swiss Plateau (Brändli 2010). Forest soils in these areas are generally not well drained due to fine texture, and thus are often wet since the climate is humid (Zimmermann et al. 2006). According to the Swiss national forest inventory, $2 \%$ of these soils are severely compacted, with a clear trend of further increase (Brändli 2010). Hence, in addition to prevention measures, it is also important to promote the regeneration of compacted soil.

Natural regeneration of compacted soil is driven by shrinkage and swelling processes due to freeze-thaw and wetting-drying cycles (Håkansson and Reeder 1994) and by the activity of roots and soil organisms such as earthworms 
(Capowiez et al. 2009; Ouellet et al. 2008). While these processes are quite effective in the topsoil, subsoil compaction can be extremely persistent (Håkansson and Reeder 1994; Thorud and Frissel 1976). In the absence of consensus about criteria to be used for assessing soil compaction (Schoenholtz et al. 2000; Tang et al. 2009), bulk density was generally used as key parameter to characterize recovery. Froehlich et al. (1985) reported that the bulk densities of compacted loamy soils in Idaho had not returned to the values of undisturbed reference soils within 23 years since logging, except for the surface horizon $(0-5 \mathrm{~cm}$ depth) of a granitic soil. Based on linear regression of bulk density data of the consequent 5 years following compaction, Dickerson (1976) estimated that wheel-rutted, compacted loamy sand and silty clay loam forest topsoils would be back to their original bulk density within 12 years. Corns (1988) studied soil compaction resulting from the employment of heavy forest harvesting machines and the effects on coniferous seedling growth at four sites with different soil parent materials, concluding that trafficked boreal forest (silty clays to silty loams) soils may remain compacted for decades. Gameda et al. (1994) found no sign of regeneration in the bulk density of clay loam soils 6 years after compaction in a Quebec forest. Likewise, Blake et al. (1976) found no decrease in bulk density 9 years after compaction of a clay loam Mollisol under agricultural use in Minnesota. Labelle and Jaeger (2011) monitored the bulk density of compacted Spodosols in eastern Canada at depths of $0.05,0.1$ and $0.3 \mathrm{~m}$ and found no significant alleviation of bulk density over a 5-year period. There are only few studies using other parameters than bulk density to assess recovery of soil structure from compaction. Alakukku (1996) showed that macroporosity was still about $70 \%$ lower than before compaction after 9 years. Brais (2001) found that 6 years after compaction due to skidding (15 skidding cycles), a fine-textured and silty clay soil in Quebec, still had $74 \%$ less macroporosity than soil without trafficking. Von Wilpert and Schäffer (2006), investigated the recovery dynamics of four compacted loamy to silty loamy forest subsoils in Germany using diffusion coefficients and rooting patterns. They concluded "that even 24 years after machine impact a transient situation was achieved rather than a complete recovery".

While little is known about the rates of structural recovery of compacted forest soils, even less is known about the effectiveness of potential measures to accelerate the structural regeneration of compacted soil. Mechanical loosening of forest soil is problematic for economic and ecological reasons and actually illegal in some countries, including Switzerland. Sinnett et al. (2008) compared different mechanical methods to loosen compacted forest soil and found that satisfactory tree growth required complete cultivation (Profiled Strip Method) to $1.1 \mathrm{~m}$ soil depth. Such a treatment is very expensive and not applicable to most forest soils, and even where it is applicable, success is not guaranteed. Gaertig et al. (2000) reported that 8 years after mechanical soil loosening by ripping, the soil was still dense under skid lanes and showed little regeneration of soil structure. Even where it can be applied "successfully", mechanical loosening may actually cause more harm than good by injuring roots (Howard et al. 1981). It generally increases the risk of secondary compaction, as soil structural stability is weakened by the disruption of aggregates (Kooistra et al. 1984).

A better alternative in order to accelerate the restoration of compacted forest soils, both in ecological and economic terms, would seem to be the use of plants. Plants are well known to promote the formation of soil structure, in particular by the mechanical action of their roots, extraction of soil moisture, exudation of cementing substances and by promoting the activities of other soil organisms (Angers and Caron 1998). In this study, we investigated the potential use of black alder (Alnus glutinosa (L.) Gaertn.) to accelerate the loosening and regeneration of a permeable, stable structure in previously compacted forest soil. Black alder is a hardy pioneer tree species, typically occurring on riparian woodlands, that is often used for melioration measures (Schmidt-Vogt 1971), such as afforestation of mining spoil areas (Lowry et al. 1962) or shoreline stabilization. Black alder is also known to be one of the deepest rooting forest tree species in central Europe (Köstler et al. 1968; Schmidt-Vogt 1971). Moreover, black alder is well adapted to anaerobic soil conditions resulting from water-logging (Armstrong and Armstrong 2005; Dittert et al. 2006; McVean 1956; Schröder 1989). Thus, our hypothesis was that it would be particularly well suited for the purpose of regenerating compacted soil. However, it was not clear how well black alder roots are able to grow in poorly aerated soil when there is also a high mechanical penetration resistance. Therefore, a field experiment was set up at two forest sites where the soil had been heavily compacted due to windfall clearance work carried out in the year 2000 after the heavy storm event "Lothar" in 1999. Black alder trees were planted into the ruts of skid lanes on both sites in 2003 to investigate:

1. The capacity of black alder to grow on compacted forest soils and penetrate them with their roots

2. The potential use of black alder to enhance the structural regeneration of compacted forest soils.

\section{Materials and methods}

Experimental sites

Both experimental sites were located in the Swiss Plateau region between the Alps and the Jura. One of the two 
experimental sites was situated near Habsburg (Canton Aargau), $20 \mathrm{~km}$ north-west of Zürich, and the other site at Messen (Canton Solothurn), $20 \mathrm{~km}$ north of Bern (Fig. 1). The soil at the Habsburg site was a Luvisol according to WRB (2006), derived from glacial melt water sediments deposited on fluvial brash. The texture according to USDA (1997) was a silt loam and the humus form mull. The original plant community was a woodruff-beech forest according to the classification proposed by Ellenberg and Klötzli (1972) before the windfall. After the clearing, the site became dominated by European hornbeam (Carpinus betulus) and birch trees, with an undergrowth of Rubus species, bracken fern (Pteridium aquilinium) and various rush species (Juncus spec.). The soil at Messen was a Gleyic Cambisol (WRB 2006), derived from glacial till covering non-marine molasse. The texture was sandy loam (USDA 1997) and the humus form active mull. Before the windfall, the plant community was a woodruff-beech forest with Luzula sylvatica according to the classification of Ellenberg and Klötzli 1972. The two sites were completely cleared between July and October 2000. After clearing, silver and white birch (Betula pendula and pubescens) and willows (Salix spec.) were the main tree species that became established spontaneously, with an undergrowth of Sambucus nigra, Rubus spec., Juncus spec. and Luzula sylvatica. Further information on local site conditions, clearance work and soil properties is given in Tables 1 and 2 .
Experimental design and soil sampling

In 2002 and 2003, all skid lanes on the two experimental sites were mapped and morphologically classified by degree of physical soil disturbance (Fig. 1). Based on this map, three replicate plots with skid lanes were chosen on each site for the experiment based on the following criteria:

1. Ruts extended through at least $0.1 \mathrm{~m}$ deep topsoil and more than $0.1 \mathrm{~m}$ deep into the subsoil, thus to a total depth of more than $0.2 \mathrm{~m}$.

2. Ruts had distinct high bulges, on average $0.1 \mathrm{~m}$ high, on both sides.

3. There was a clearly visible mixing of organic and mineral soil layers.

On each site, soil samples were taken at $0.2-0.3 \mathrm{~m}$ depth below tracks with severe soil compaction (three samples) and from a soil profile of an untrafficked reference plot (three samples), using sharpened steel cylinders, in order to determine soil bulk density and porosity prior to planting. Additional soil samples were taken from skid lanes, irrespectively of disturbance degree, across the experimental sites and analysed for soil texture. These analyses confirmed the impression obtained from visual site inspection during skid lane mapping that the two sites were sufficiently homogeneous for the experiment, in agreement with the delineation of mapping units in available plant community (a)

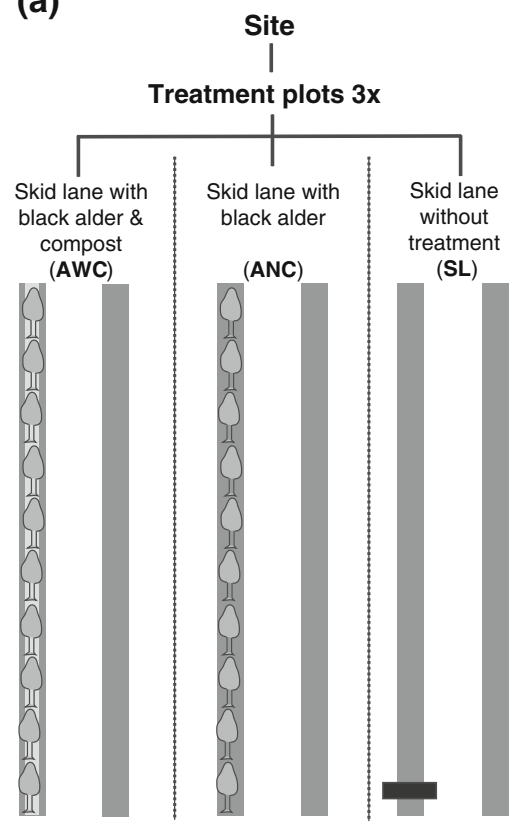

(b)

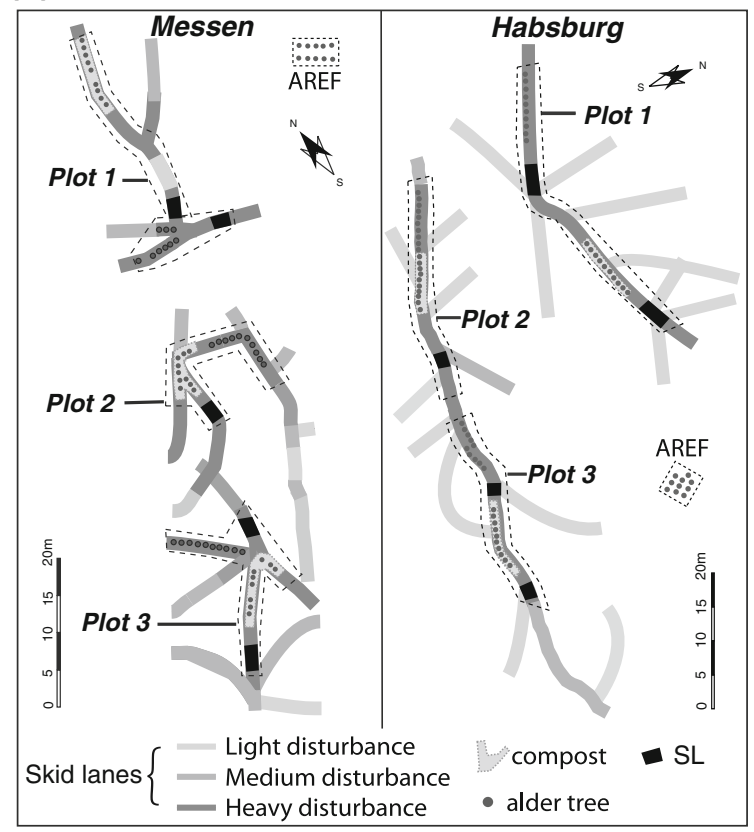

Fig. 1 a Scheme of the experimental design. b Situation of the study sites, showing the position of the experimental plot areas $(1,2$, $3=$ replicates) relative to the spatial pattern of skid lanes and their disturbance levels on each site. All three experimental skid lane treatments were established in one sub-plot on each plot 
Table 1 Physiographic characteristics of the two experimental sites at Habsburg and Messen and information relating to machinery and soil protection measures used in the clearing operations in the year 2000 after the windfall

\begin{tabular}{|c|c|c|}
\hline & Messen & Habsburg \\
\hline \multicolumn{3}{|l|}{ Climate (mean annual) } \\
\hline Temperature $\left({ }^{\circ} \mathrm{C}\right)$ & 9.4 & 9.5 \\
\hline Precipitation & $1,187 \mathrm{~mm}$ & $1,032.5 \mathrm{~mm}$ \\
\hline \multicolumn{3}{|l|}{ Topography } \\
\hline Elevation (a.s.l.) & $510-530 \mathrm{~m}$ & $445-455 \mathrm{~m}$ \\
\hline Relief & Slope, northeast-facing, $0-5 \%$ & Slope, east-facing, $0-5 \%$ \\
\hline Plant community & $\begin{array}{l}\text { woodruff-beech forest } \\
\text { with Luzula sylvatica }\end{array}$ & woodruff-beech forest \\
\hline \multicolumn{3}{|l|}{ Clearing work } \\
\hline Machines & $\begin{array}{l}\text { Landini, Timberjack } 1270 \mathrm{~B} \text {, } \\
\text { Forwarder Valmet } 820\end{array}$ & $\begin{array}{l}\text { Harvester COBRA HS10, } \\
\text { Timberjack 360C, Forwarder } \\
\text { Timberjack } 1110\end{array}$ \\
\hline Soil protection measures & None & Twig mats \\
\hline
\end{tabular}

Table 2 Soil $\mathrm{pH}$ (median), grain-size fractions, $\mathrm{C} / \mathrm{N}$ ratios and carbon contents (averages with standard errors in parentheses) of the soil samples collected in 2009 and 2010 from the two experimental sites

\begin{tabular}{lcc}
\hline & Messen & Habsburg \\
\hline Soil pH & 3.8 & 3.3 \\
Clay $^{\mathrm{b}}\left(\mathrm{kg} \mathrm{kg}^{-1}\right)$ & $0.139(0.019)$ & $0.181(0.030)$ \\
$\mathrm{Silt}^{\mathrm{b}}\left(\mathrm{kg} \mathrm{kg}^{-1}\right)$ & $0.328(0.065)$ & $0.546(0.032)$ \\
${\mathrm{Sand}\left(\mathrm{kg} \mathrm{kg}^{-1}\right)}_{\text {Gravel }\left(\mathrm{m}^{3} \mathrm{~m}^{-3}\right)}$ & $0.533(0.075)$ & $0.273(0.044)$ \\
$\mathrm{C} / \mathrm{N}$ & $0.007(0.001)$ & $0.111(0.010)$ \\
$\mathrm{C}\left(\mathrm{g} \mathrm{kg}^{-1}\right)$ & $12.07(2.58)$ & $15.2(2.42)$ \\
\hline
\end{tabular}

${ }^{\mathrm{a}}$ In $0.01 \mathrm{M} \mathrm{CaCl}_{2},{ }^{\mathrm{b}}$ pipette method

and soil maps. Due to the small number of samples analysed for porosity and bulk density and the fact that their sampling locations did not exactly match the sampling design used in 2009 and 2010, as given below, we chose not to include these data in the statistical analysis of the latter samples, but only as supplementary information on the initial state of the experimental areas before tree planting.

In 2003, two-year-old black alder (Alnus glutinosa (L.) Gaertn.) seedlings (origin CH Birmensdorf, WSL seed bank, $550 \mathrm{~m}$ a.s.l.) were planted into $0.15 \mathrm{~m}$ deep and $0.10 \mathrm{~m}$ broad holes that were excavated by means of a spade in the rut beds of the selected skid lanes. On each of the three plots per site, 20 experimental trees were planted at a distance of $1.2 \mathrm{~m}$ between them. As an additional treatment, half of the selected and planted ruts in each plot were filled (to the height of the bulges) with compost after planting. As a result, there were ten trees in each of the two treatments AWC (subplot with compost) and ANC (subplot without compost) on each plot. As a control, subplots with no treatment (SL) were also established in some skid lanes on each plot. Furthermore, a non-trafficked open plot was selected as close as possible to the trafficked area on each site and planted with black alders (ten trees) as a reference plot (AREF) for alder growth on uncompacted soil (Fig. 1b). The compost consisted of decomposed mixed wood chips (hardwoods and coniferous woods) and plant litter from the WSL tree nursery garden and had a neutral pH. In each AWC subplot, $73 \mathrm{~kg}\left(\approx 1.1 \mathrm{~m}^{3}\right)$ of compost was evenly distributed over a skid lane length of $14 \mathrm{~m}$, filling the tracks up to the height of the bulges. The compost was added manually and lightly tamped into the rut beds. Spontaneous growth of other trees and rush plants close to the planted trees was regularly removed in the first 2 years in order to minimize competition for light.

At the end of the experiment, soils were sampled from the experimental plots at Habsburg between June and October 2009 and at Messen between April and October 2010. On some plots, we sampled one soil profile, in others two profiles per treatment, depending on space and time constraints. Overall, we sampled 4 profiles each for AWC and ANC, 3 profiles for AREF and 5 profiles for SL $(=16$ profiles in total) at Habsburg and 5 profiles for each (including AREF) subplot ( $=20$ profiles in total) at Messen. The profiles $(0.8 \mathrm{~m}$ depth, $1.20 \mathrm{~m}$ width) were excavated across the skid lanes in the case of the AWC, ANC and SL subplots and at $0.2 \mathrm{~m}$ distance from the stem base of a randomly selected tree in the case of the subplots with alders (ANC, AWC and AREF). Three samples were taken at $0.2-0.3 \mathrm{~m}$ depth from each profile by means of sharpened steel cylinders ( $1 \mathrm{~L}$ volume). In the case of the skid lane subplots, the samples were taken from beneath the ruts and the depth refers to the undisturbed soil surface next to the ruts. The samples were kept in the cylinders and stored at $4{ }^{\circ} \mathrm{C}$ in a cooling chamber, until they were analysed.

Prior to sampling, we assessed macroscopic soil characteristics in our sampling profiles using standard procedures (Zimmermann et al. 2006) and recorded rootmorphological features. In addition, we surveyed the composition of the vegetation on and adjacent to the skid lanes using a standard protocol. 
Measurements

The height of all trees was measured annually on both sites from autumn 2003 to 2005 . Tree heights were again measured together with stem diameter at breast height (DBH) when the soil samples were taken in autumn 2009 at Habsburg (per treatment $n=26-30$, trees with crown breakage excluded) and in 2010 at Messen (per treatment $n=27-30$ ). Root biomass was determined from the soil profile samples after the soil physical measurements (see below).

To characterize the structural regeneration of the compacted soil, we determined the following soil physical parameters: bulk density, total porosity, coarse porosity and air permeability. The analysis proceeded as follows. The samples were first water-saturated, weighed, desorbed to a water potential of $-6 \mathrm{kPa}$ on a sand bed by applying a hanging water column, and weighed again to determine the drained pore volume, which we defined as coarse porosity (AG-Boden 1982; Berli et al. 2004; Schäffer et al. 2007a, b). Then, air permeability was measured on the drained and weighed samples using the method of Delage et al. (1998), with a slightly modified experimental set-up. The sample was installed in an airtight pipe collar system (Straub Flex 1L, 108.0, Straub Werke AG, CH-7323 Wangs). On one side, the sample was connected through a tube to a $120 \mathrm{~L}$ tank volume (two tanks of $60 \mathrm{~L}$ volume each), a manometer and a vacuum pump, on the other side via a valve to the ambient atmosphere. Prior to each test, air was pumped out of the vacuum tank until the pressure was $-12.6 \mathrm{hPa}$ relative to the ambient air. After opening the valve, we recorded the reduction in air pressure in the system over time, as air was flowing through the sample into the vacuum tank, until the pressure had dropped to $1 \mathrm{hPa}$. Air permeability was then calculated from the resulting experimental curve.

Thereafter, the samples were oven-dried at $105{ }^{\circ} \mathrm{C}$ for $48 \mathrm{~h}$, weighed again to determine bulk density, and sieved to remove gravel (mineral particles coarser than $2 \mathrm{~mm}$ ) and roots. The latter were weighed separately to determine root mass density. The pore volume desorbed between $-6 \mathrm{kPa}$ water potential and oven-drying was interpreted as fine-tointermediate porosity. Total porosity was calculated as the sum of coarse and fine-to-intermediate porosity. Volumetric gravel content was calculated assuming an average particle density of $2.65 \mathrm{~g} \mathrm{~cm}^{-3}$. By subtracting the volumetric gravel content from the total sample volume, we obtained the fineearth volume, which was used-following Schäffer et al. (2007a) - to calculate fine-earth bulk density $\mathrm{BD}_{\mathrm{fe}}$, coarse porosity $\mathrm{CP}_{\text {fe }}$, fine-to-intermediate porosity $\mathrm{FIP}_{\mathrm{fe}}$ and total porosity $\mathrm{TP}_{\mathrm{fe}}$ by means of the following equations:

$\mathrm{BD}_{\mathrm{fe}}=\left(m_{\text {sample }}-m_{\text {coarse fraction }}\right) /\left(V_{\text {sample }}-V_{\text {coarse fraction }}\right)$

$$
\begin{aligned}
& \mathrm{CP}_{\mathrm{fe}}=V_{\text {coarse pores }} /\left(V_{\text {sample }}-V_{\text {coarse fraction }}\right) \\
& \mathrm{FIP}_{\mathrm{fe}}=V_{\text {fine-to-intermediate pores }} /\left(V_{\text {sample }}-V_{\text {coarse fraction }}\right) \\
& \mathrm{TP}_{\mathrm{fe}}=\mathrm{CP}_{\mathrm{fe}}+\mathrm{FIP}_{\mathrm{fe}}
\end{aligned}
$$

where the subscript fe denotes fine earth, $m$ stands for mass and $V$ for volume.

After the physical measurements, the fine-earth samples were analysed for $\mathrm{pH}$ and $\mathrm{C} / \mathrm{N}$ ratios. Soil $\mathrm{pH}$ was measured potentiometrically in $0.01 \mathrm{M} \mathrm{CaCl}_{2}$. To determine $\mathrm{C} / \mathrm{N}$ ratios, subsamples were dried, milled and analysed for $\mathrm{C}$ and $\mathrm{N}$ using an automated elemental analyser-continuous flow isotope ratio mass spectrometer (Euro-EA, Hekatech GmbH, Germany, interfaced with a Delta-V Advanced IRMS, Thermo GmbH, Germany).

Statistical analysis

Statistical analyses of soil physical parameters, root mass density and DBH were performed separately for each site using linear mixed-effects models. Plots (blocks) and profiles (or trees for DBH) were considered as nested random effects and treatments as fixed effects. Differences between treatments were tested with the post hoc Tukey HSD procedure, using the $\mathrm{R}$ routines nlme and multcomp ( $\mathrm{R}$ Development Core Team 2011). The data for air permeability and root mass density were log-transformed prior to the tests to fulfil the criterion of normal distribution. Differences with $P<0.05$ were considered significant. To test for differences in tree height growth between year and sites, linear mixed-effects models were used. Site was either included as a random or fixed effect and year as fixed effect. Spearman's rank-correlation coefficients between root mass density and all physical parameters were calculated for the ensemble of samples from all treatments of a site, except AREF. The minimum level of significance was set at $P=0.01$ (conservative Bonferroni adjustment) for these coefficients to account for multiple comparisons. As we only had pseudo-replicates for the AREF subplots and too few data from the preliminary investigations in 2003 (see above), these data were not included in the statistical analysis and only used as supplementary information. All statistical analyses were performed using the statistical software package R (R Development Core Team 2011).

\section{Results}

Tree growth and root mass density

None of the experimental trees showed symptoms of biotic or abiotic stress at the time of final sampling and before. In 
the AWC and ANC treatments, there were no significant differences in tree height growth between the two sites, whereas trees grew significantly higher on the AREF subplot at Habsburg than at Messen $(P \leq 0.05$ for all years from 2004 until 2009, Fig. 2). From the second experimental year on, the trees were much larger $(P \leq 0.05$ until $2005, P \leq 0.005$ in 2009) on the AWC and ANC plots than on the AREF plots on both sites (Fig. 2), while there was no significant difference between the AWC and ANC treatments, except for 2005 at Habsburg $(P \leq 0.04)$. In all treatments, the diameter at breast height $(\mathrm{DBH})$ was lower at Messen than at Habsburg $(P=0.02)$. Like tree height, the DBH was also larger on the AWC and ANC than on the AREF subplots on both sites, with no significant differences between the AWC and ANC treatments (Fig. 3). As expected, root mass density, i.e. the root biomass per unit mass of soil, was higher in the AWC and ANC than in the SL treatments on both sites (Fig. 4). At Messen, the highest root densities were found in the AWC treatments, while they were highest in the ANC treatments at Habsburg, although the differences between the two treatments were not significant at both sites, due to the large variability among the replicate plots. Most of the few roots found in the SL treatments were dead and had presumably already been produced in the old stand before the "Lothar"
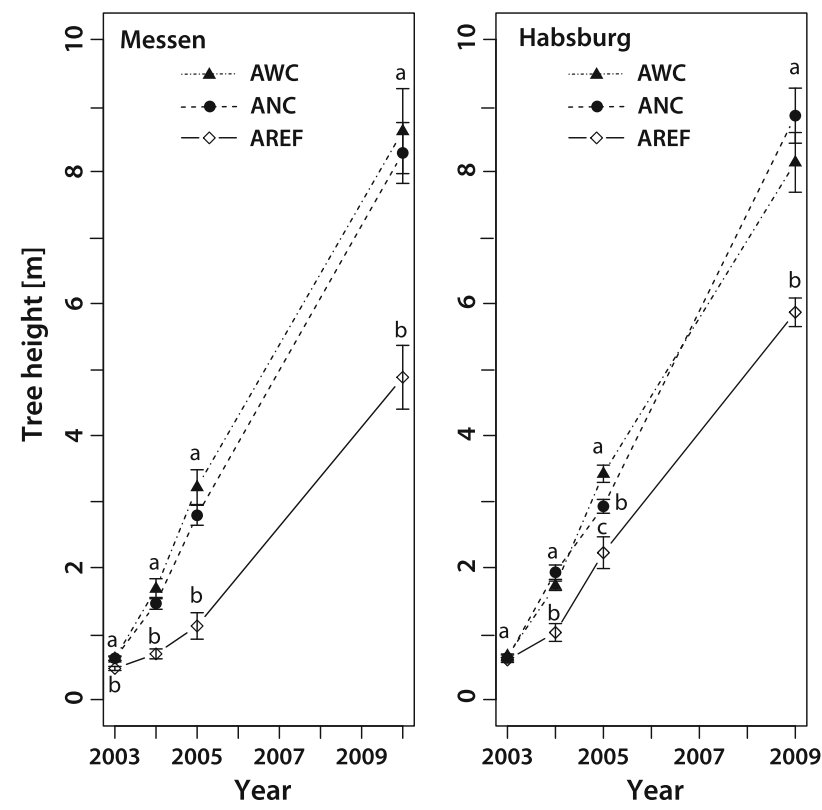

Fig. 2 Height growth of black alder trees planted on the experimental and reference plots at Messen (left) and Habsburg (right). Points represent treatment means, and error bars represent standard errors. Treatments: AWC alders planted in skid lanes with compost application, ANC alders planted in skid lanes without compost application, AREF alders on untrafficked reference plots. Average values (per year) followed by same letter did not differ significantly at a $5 \%$ significance level
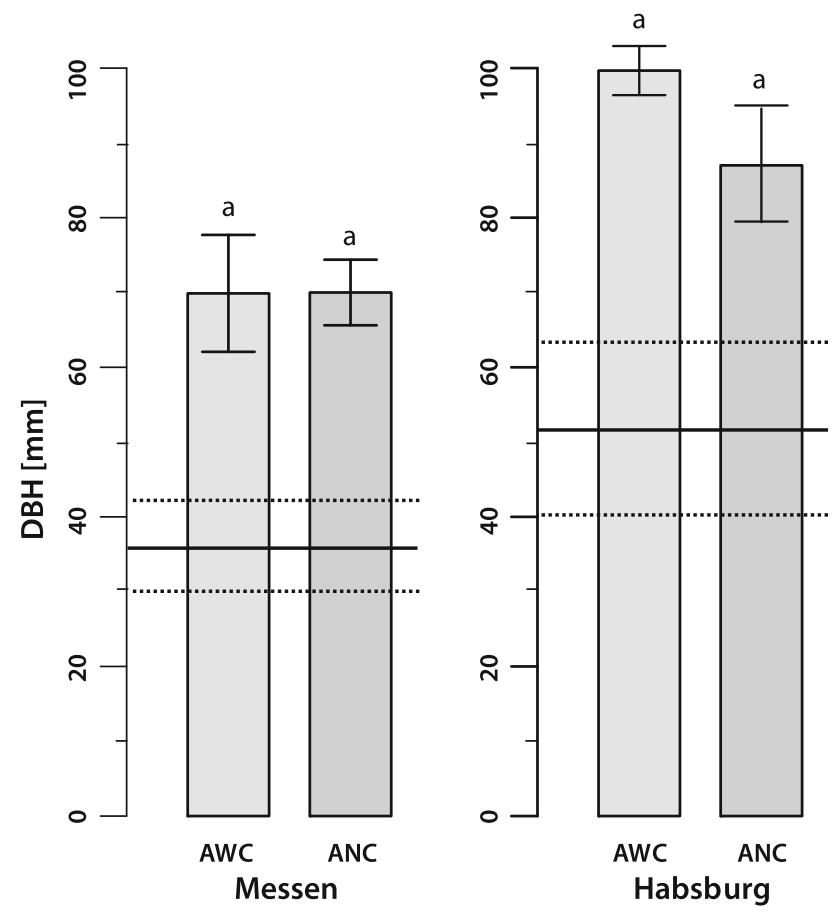

Fig. $3 \mathrm{DBH}(\mathrm{mm})$ of black alder trees planted at Messen (left) and Habsburg (right). Error bars represent standard errors. The horizontal lines give the average \pm standard error for the respective reference plot (AREF). Average values followed by same letter did not differ significantly at a $5 \%$ significance level
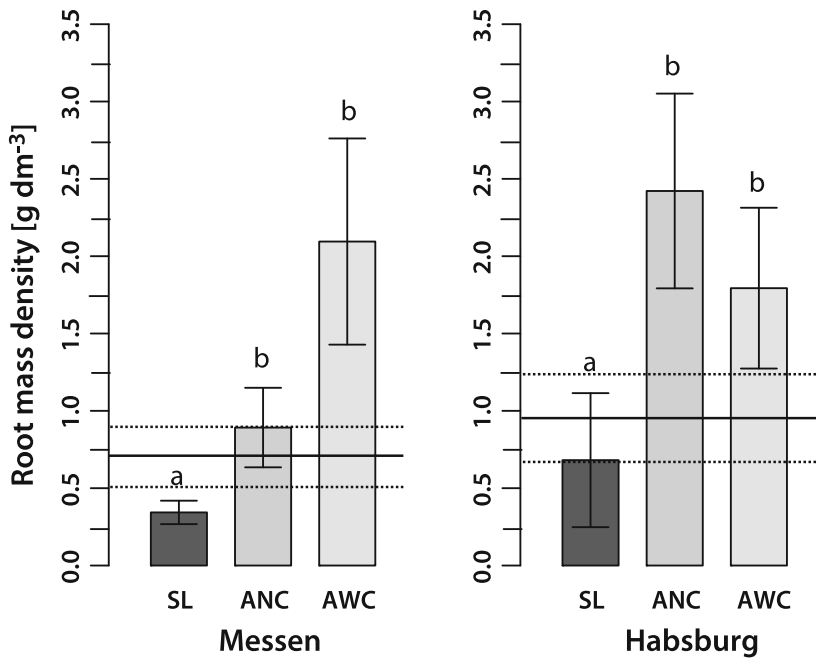

Fig. 4 Root mass density $\left(\mathrm{g} \mathrm{dm}^{-3}\right)$ at $0.2-0.3 \mathrm{~m}$ depth at Messen (left) and Habsburg (right). Error bars represent standard errors. The horizontal lines give the average \pm standard error for the respective reference plot (AREF). Average values followed by same letter did not differ significantly at a $5 \%$ significance level

windfall. In line with the lower aboveground growth on the AREF plots, the average values of root density were for both sites also lower in the AREF than in the AWC and ANC samples, although the difference between ANC and AREF was only small at Messen. 
Morphological observations

\section{Root growth}

During preparation of the soil profiles for sampling, we observed that some roots had grown down to $0.8 \mathrm{~m}$ depth in all treatments, although the bulk of root biomass was in the upper $0.2 \mathrm{~m}$ of the soil. Very little root growth below $0.2 \mathrm{~m}$ was observed, especially in the AWC treatment at Habsburg. Here, the roots of most AWC trees were flattened (and not cylindrical) below $0.3 \mathrm{~m}$ depth. Flattened roots at lower depths were also found at Messen, but primarily in the ANC treatments. Furthermore, we found that many AWC and some ANC trees formed adventitious roots (approximately $3 \mathrm{~mm}$ diameter, $6 \mathrm{~cm}$ long) at the lower stem base (up to $0.2 \mathrm{~m}$ above the soil surface) at Habsburg during periods of intensive rainfall. These roots died back 3-6 weeks after these periods.

\section{Qualitative soil characteristics in relation to treatments}

The larger thickness of the organic layers and their much more distinct separation from the mineral soil beneath in the sampled soil profiles indicated that litter decomposition was slower and that there was less biological turbation at Habsburg than at Messen (Table 2). In line with these differences, there was still a clearly visible border between the upper part of the profile filled with compost residues and the mineral soil below at Habsburg in 2009, while there was no visible border between compost and mineral soil at Messen. In contrast to Messen, roots did penetrate much less deeply into the mineral soil at Habsburg and were concentrated in the compost layer.

One of the most conspicuous differences between the skid lanes of the two study sites was the extent of the lateral bulges that had been present on the sides of the ruts initially, and were of similar size at both sites when the tracks were mapped prior to the experimental planting in 2003. While these bulges were still clearly visible and the rut beds were lying below the soil surface adjacent to the tracks at Habsburg, they were barely visible (SL) or no longer visible at all (AWC/ANC) at Messen when we sampled the soil profiles in 2010. The most distinctive feature of the skid lanes at Messen was that their vegetation cover, as far as there was any, was different from their immediate neighbourhood (unpublished data, determined using the "Zürich-Montpellier School" method of BraunBlanquet). The rut beds showed high abundances of rush (i.e. Luzula luzuloides, Juncus effusus) and sedge species (i.e. Carex remota), with coverage ratios of 4 (50-70\% coverage). Other species like brambles or seedlings of trees, which grew in the neighbourhood, were not abundant in the ruts $(r=$ seldom, less than 3 specimens, $<1 \%$ coverage). At Messen, some ruts were dominated by Glyceria fluitans, a grass (Poaceae) normally occurring on wet sites such as ditches, riverbanks and ponds. The vegetation cover was in general denser alongside the ruts $(80 \%)$ than on the ruts (50-60\%), except for the ruts dominated by Glyceria. During sampling, we also observed a higher abundance of earthworms in the AWC and ANC soil profiles than in the SL profiles, while most earthworms were found in the AREF profiles (data not shown).

\section{Soil physical parameters}

The soil physical parameters (bulk density, total porosity, coarse porosity and air permeability) analysed in this study in general showed values for the AWC and ANC treatments lying between those of the AREF plots and the SL subplots (Figs. 5, 6, 7, 8). In those cases where the differences between SL and ANC subplots or SL and AWC subplots were statistically not significant, there were at least consistent trends. The only exception was the porosity of the ANC samples from Messen, which was on average the same as that of the SL samples (Fig. 6). Lack of significance in differences between treatments was in general the result of large variability within profiles rather than among subplots. The soil physical treatment effects showed similar patterns on both sites. The main difference was that the alder treatment with compost application (AWC) resulted in slightly stronger effects (n.s.) than the alder treatment without compost (ANC) relative to the treatment with no planting (SL) at Messen, whereas at Habsburg,
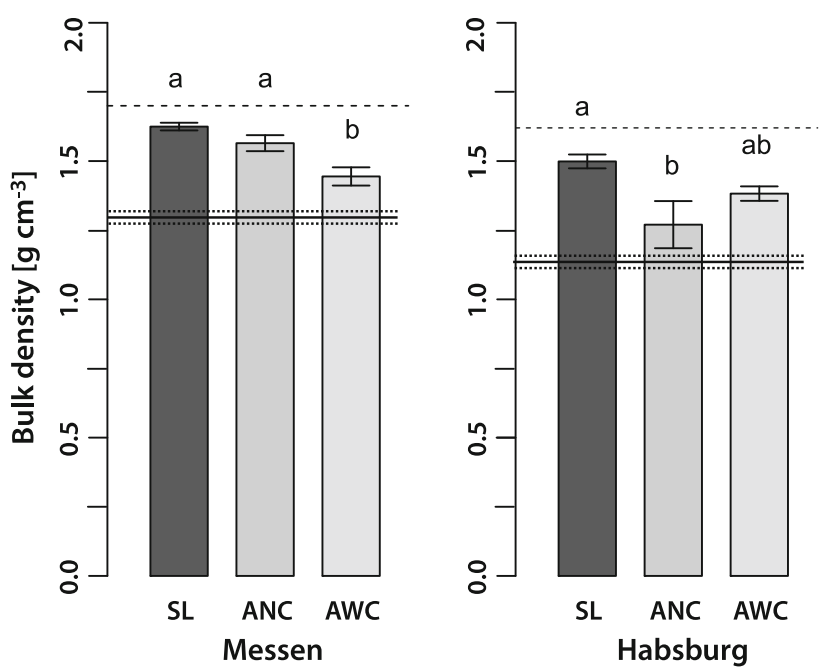

Fig. 5 Fine-earth bulk density at $0.2-0.3 \mathrm{~m}$ depth at Messen (left) and Habsburg (right). Error bars represent standard errors. The continuous horizontal lines give the average \pm standard error for the respective reference plot (AREF). The broken line gives the respective average value from the preliminary investigations. Average values followed by same letter did not differ significantly at a $5 \%$ significance level 

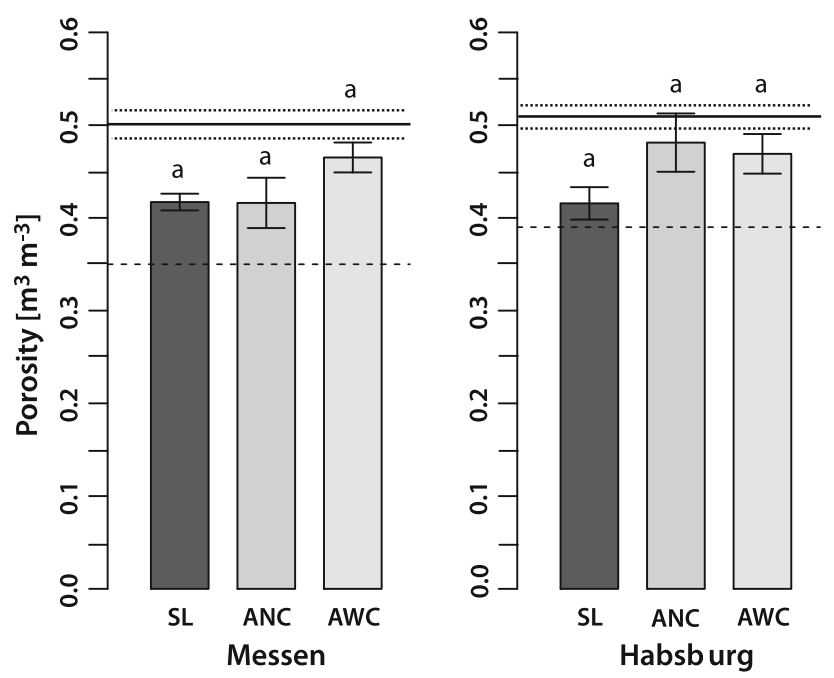

Fig. 6 Total soil porosity at $0.2-0.3 \mathrm{~m}$ depth at Messen (left) and Habsburg (right). Error bars represent standard errors. The continuous horizontal lines give the average \pm standard error for the respective reference plot (AREF). The broken line gives the respective average value from the preliminary investigations. Average values followed by same letter did not differ significantly at a $5 \%$ significance level
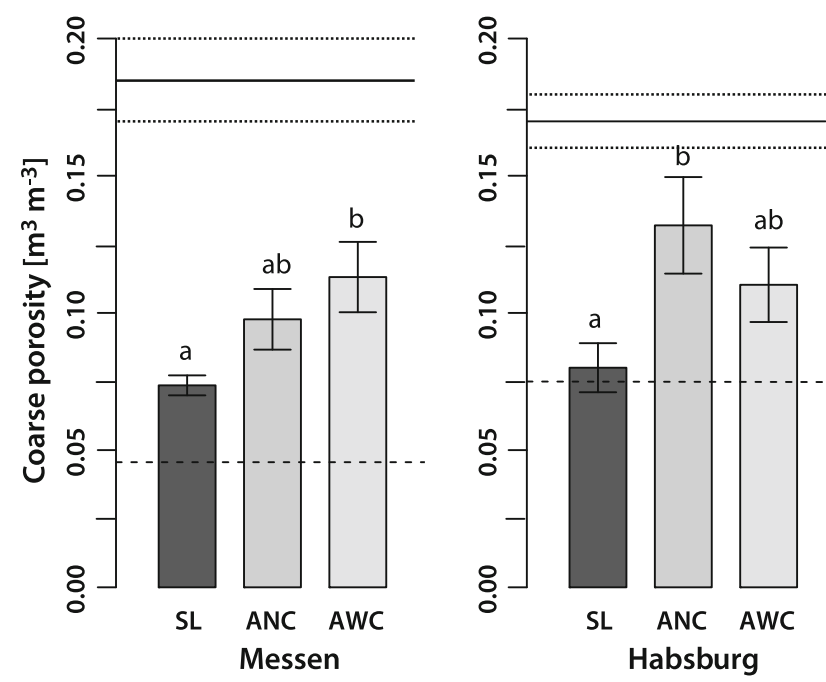

Fig. 7 Coarse porosity of the fine earth at $0.2-0.3 \mathrm{~m}$ depth at Messen (left) and Habsburg (right). Error bars represent standard errors. The continuous horizontal lines give the average \pm standard error for the respective reference plot (AREF). The broken line gives the respective average value from the preliminary investigations. Average values followed by same letter did not differ significantly at a $5 \%$ significance level

the ANC treatment had slightly stronger effects than AWC, paralleling the corresponding patterns of effects on root mass density (Fig. 4).

The comparison between the results of the alder plots (AWC and ANC) with the unplanted plots (SL) shows that a substantial development in pore structure had occurred in
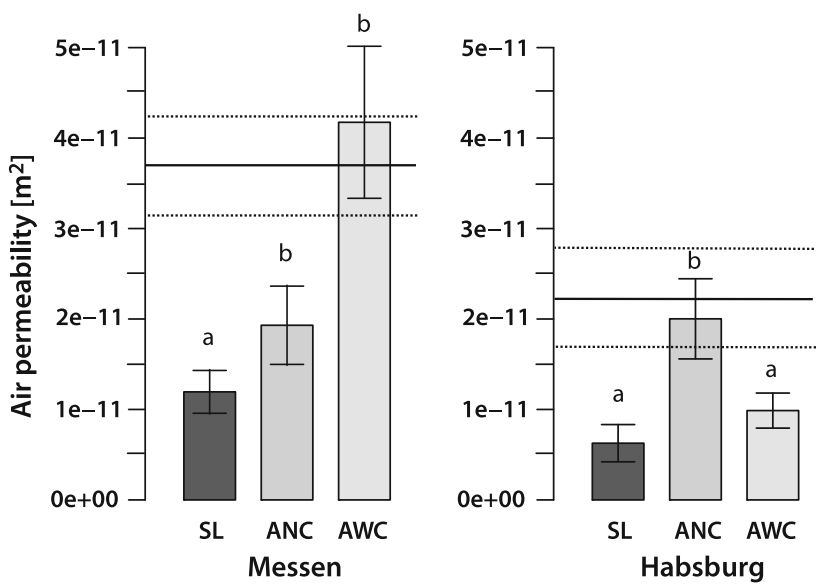

Fig. 8 Air permeability at $0.2-0.3 \mathrm{~m}$ depth at Messen (left) and Habsburg (right). Error bars represent standard errors. The horizontal lines give the average \pm standard error for the respective reference plot (AREF). Average values followed by same letter did not differ significantly at a $5 \%$ significance level

the 6-7 years of the experiment in the alder treatments (Figs. 6, 7). Unfortunately, no true replicate samples were collected prior to the experiment. Thus, it was not possible to determine whether there was also a significant structural change in the control treatment (SL). The bulk density and porosity measurements suggest that this was the case for Messen, while they did less so or not at all for Habsburg (Figs. 6, 7). Intriguingly, the AREF plots always gave the highest total and coarse porosity values and the lowest bulk density values. This indicates that the structural regeneration of the planted skid lane soils was still not complete, even though the lack of true AREF replicates does not allow for comparison in a rigorous statistical sense. Only the air permeability of the AWC samples from Messen and the ANC samples from Habsburg was the same as that of the respective AREF samples.

The data available from the initial sampling in 2003 were very similar to those from our sampling at the end of the experiment for the AREF plots, suggesting that the physical structure of the untrafficked reference plots did not change during the experiment. Initial bulk density in the untrafficked reference sites (AREF) was $1.32 \pm 0.03 \mathrm{~g} \mathrm{~cm}^{-3}$ at Messen and $1.13 \pm 0.04 \mathrm{~g} \mathrm{~cm}^{-3}$ at Habsburg, while initial porosity was $0.57 \pm 0.06 \mathrm{~m}^{3} \mathrm{~m}^{-3}$ at Messen and $0.50 \pm 0.02 \mathrm{~m}^{3} \mathrm{~m}^{-3}$ at Habsburg, and initial coarse porosity was $0.2 \pm 0.5 \mathrm{~m}^{3} \mathrm{~m}^{-3}$ at Messen and $0.175 \pm 0.03 \mathrm{~m}^{3} \mathrm{~m}^{-3}$ at Habsburg. In comparison, the difference between initial values and the respective data from the SL plots was generally larger than the standard errors, which again indicates that some structural development also occurred in the plots without alders.

It is interesting to note that the air permeability of the Habsburg samples was lower than that of the corresponding Messen samples (Fig. 8), while the opposite was true for 
Table 3 Spearman coefficients of the correlations between root mass density, fine-earth bulk density, fine-earth coarse porosity, total porosity and air permeability over all treatments per experimental site

\begin{tabular}{|c|c|c|c|c|c|c|}
\hline Site & Parameter & Root mass density & Bulk density & Coarse porosity & Total porosity & Air permeability \\
\hline \multirow[t]{5}{*}{ Messen } & Root mass density & 1.0 & & & & \\
\hline & Bulk density & $-0.66 * *$ & 1.0 & & & \\
\hline & Coarse porosity & $0.53^{* *}$ & $-0.70 * *$ & 1.0 & & \\
\hline & Total porosity & $0.54 * *$ & $-0.79 * *$ & $0.53 * *$ & 1.0 & \\
\hline & Air permeability & 0.24 & -0.29 & $0.35^{*}$ & 0.22 & 1.0 \\
\hline \multirow[t]{5}{*}{ Habsburg } & Root mass density & 1.0 & & & & \\
\hline & Bulk density & $-0.66 * *$ & 1.0 & & & \\
\hline & Coarse porosity & $0.51^{*}$ & $-0.71 * *$ & 1.0 & & \\
\hline & Total porosity & $0.54 * *$ & $-0.80 * *$ & $0.50 * *$ & 1.0 & \\
\hline & Air permeability & 0.30 & -0.33 & $0.52 *$ & 0.25 & 1.0 \\
\hline
\end{tabular}

To account for multiple comparisons, the minimum level of significance was set to $P=0.01$ (conservative Bonferroni adjustment)

* $P<0.01 ; * * P<0.001$

the coarse porosity. As there was generally less air-filled porosity in the Messen samples at field capacity, the higher air permeability means that this porosity had a higher degree of connectivity. Variability in connectivity would also explain why air permeability was less strongly correlated to the other parameters than they were correlated to each other (Table 3). As was expected, bulk density showed particularly close negative correlations to total and coarse porosity as well as root mass density on both sites, while air permeability exhibited a significant positive correlation only to coarse porosity. The correlation coefficients were nearly the same for both sites, except for the correlation between air permeability and coarse porosity. In this case, there was a closer correlation for Habsburg than for Messen, indicating a stronger influence of a macroporerelated but not closely root-dependent factor on air permeability at the latter site.

\section{Discussion}

Tree growth and root development

The results show that the planted black alder trees grew extremely well on both sites, especially in the compacted skid lane soils. An average height of around $8 \mathrm{~m}$ reached within 6-7 years of growth is extraordinary compared to values reported in the literature. Glavac (1972), who studied three different sites in Germany, Finland and (former) Yugoslavia, reported similar values ranging between 7.2 and $8.6 \mathrm{~m}$, but for 10-year-old black alder trees. SchmidtVogt (1971) measured heights of only 5.1-6.2 $\mathrm{m}$ in 10-yearold black alder trees of different origins grown in Teisendorf (Germany) on a site with comparable climatic condition as on our study sites. The strongly accelerated growth in the skid lane treatments compared to the non-compacted reference areas was not expected. Most studies examining impacts of soil compaction on plant growth in agriculture and forestry found negative effects on plant growth (Bassett et al. 2005; Froehlich 1979; Hildebrand 1983). While some studies showed that plant growth can also be enhanced by soil compaction, compaction was only moderate in these studies and the soil that was initially rather loose and dry (Alameda and Villar 2009; Arvidsson 1999; Brais 2001; Passioura 2002; Schäffer et al. 2007a, b; Tracy et al. 2011). Thus, the increased growth on compacted soil could be attributed to improved root-soil contact and water holding capacity. At our experimental sites, the soils of the reference plots were neither particularly loose nor dry, and the herbaceous ground vegetation showed more vigorous growth adjacent to rather than in the skid lanes. Given that (1) the soils were initially the same on the ANC and AREF plots (2) the tree heights on the reference plots AREF were still comparable to those reported from other sites (see above) (3) the compost treatment had no effect on aboveground growth and (4) we did not observe any nutrient deficiency symptoms in the leaves, we exclude nutrient deficiency as a growth-limiting factor on the AREF subplots in our experiment. Most likely, the skid lanes provided better moisture conditions for the growth of alders than the reference plots. While black alders are known for high water consumption (Claessens et al. 2010; Ellenberg 1996; Eschenbach and Kappen 1999), they do not suffer from water-logging during moist periods due to the tolerance of these trees to anaerobic soil conditions. Impeded run-off and drainage may thus have been advantageous for the trees on the skid lanes by sustaining more tree growth during drier periods. In addition, the compaction may also have enhanced the water holding capacity of the skid lane soils. We would expect the latter effect to be more beneficial for tree growth on the sandy 
loam at Messen than on the silty loam at Habsburg. This is, in fact, in line with the relative magnitude of the observed growth effects at the two sites.

Our observations on black alder root growth agree with those of Kreutzer (1961), who found that black alder roots had the capacity to grow much better into naturally compact and wet phyllite soils than the roots of other tree species (e.g. different Quercus species, Carpinus betulus, Abies alba). The observation of flattened roots in the compacted soil below $0.3 \mathrm{~m}$ depth, however, also indicates that the capacity of alder roots to grow into compacted soil is limited and was inhibited in the skid lanes by mechanical resistance. The occurrence of adventitious rooting is usually observed during water-logging periods and indicates oxygen deficiency (Gill 1975). These adaptations help black alder roots cope with oxygen deficiency in soil and also help sustain growth under pro-longed water-logging conditions (Gill 1975), as long as anaerobic conditions are not permanent (Eschenbach and Kappen 1999).

\section{Soil physical aspects}

Planting black alders clearly enhanced the regeneration of soil structure in our experiment. Although the experiment was not designed to answer this question, the available data suggest that some regeneration also occurred without alders. The fact that the parameter values of the samples representing the initial state of the non-trafficked soils in 2003 are in agreement with the data obtained from AREF sites indicates that the initial sampling represented the untrafficked soil well. Assuming that this was also the case for the skid lanes, the data indicate that some regeneration also took place in the SL, especially at Messen. In particular, this would suggest that bulk density decreased between 0.2 and $0.3 \mathrm{~m}$ in the SL treatment, which is a quite distinct effect in comparison with other studies. The differences between Messen and Habsburg indicate a soil texture and acidity effect. A faster regeneration of physical structure in the less acidic sandy loam at Messen than in the more acidic silt loam at Habsburg is consistent with the results of Page-Dumroese et al. (2006), who analysed various North American soils 1 and 5 years after compaction and also found a greater decrease in bulk density in sandy loam than in silt loam.

While the results suggest a direct relationship between soil structure regeneration and root system development, they say nothing about the nature of the underlying interactions. Roots can not only grow into already existing cracks and fissures, but also create new pores by penetrating the soil matrix (Angers and Caron 1998). By extracting soil water, they promote the formation of aggregates and thus interaggregate pore space through shrinkage (Angers and Caron 1998; Materechera et al. 1994; Tri 1968), as well as in soil that is not in direct root contact. Pores created by root penetration are generally in the size range of coarse pores, like visible cracks formed through hydraulic soil shrinkage (Gibbs and Reid 1988). The fact that these pores in general also tend to be continuous over longer distances than finer pores (Beven and Germann 1982) explains why the alder treatments increased coarse porosity and air permeability in particular. There are also opposite effects of roots on the soil pore space that is available for water and air. Expanding roots compress the surrounding soil, and pore space occupied by roots is blocked for water and air (Dexter 1987). However, the important structural effect is the change in pore size distribution, as the volume of coarse pores is enlarged while that of medium to fine pores is reduced (Dorioz et al. 1993). This results in net pore space being generated as soil is pushed upwards by root thickening and by burrowing soil faunal activity, which is also promoted by the development of roots and associated with an improvement in living conditions. Moreover, it should also be considered that living roots usually do not fill out their channels completely. Using X-ray tomography, Carminati et al. (2009) showed how dehydration led to pronounced gaps between shrinking roots and soil. Black alders are known for a high root turnover rate (Köstler et al. 1968), and, as the decay of roots frees biopores for air and water, this may be an additional benefit of alder root systems in regenerating soil structure compared to trees with less root turnover.

As our experimental design was not fully factorial (no skid lanes with compost but without trees), the benefit of the compost treatment can only be evaluated in combination with trees. However, we consider this adequate, as indeed the idea behind compost application was primarily to enhance tree growth and its effect on the regeneration, which was the main effect in this study. The effects of the compost treatment on soil structure regeneration and root densities differed considerably between the two sites, but showed consistency within each site that was similar to that of the alder treatment. While the enhancement of root mass density and soil structure development at Messen was in line with our expectation that compost would benefit structure regeneration by stimulating soil biological activity and promoting root growth, the lack of such effects and the tendency even for the opposite effects at Habsburg show that the picture is more complex than that. The distinctly sharper boundary between the organic layer and the mineral soil beneath, which was also observed in nontrafficked soil, indicated that biological activity was generally much lower at Habsburg than at Messen, a difference that is also reflected in the wider $\mathrm{C} / \mathrm{N}$ ratios of the soil samples from Habsburg. Reduced soil biological activity at Habsburg may have been due to the lower soil $\mathrm{pH}$ values, as the soil samples from Messen were generally less acidic. However, the difference in $\mathrm{pH}$ compared to the soil at 
Habsburg was relatively small. Thus, while it is possible that soil biological activity was particularly sensitive to $\mathrm{pH}$ in the range of acidity of the two sites (Kemmitt et al. 2006), it seems likely that also other differences, e.g. in mineral nutrient availability, between the two soils played a role here as well. High sensitivity to rather small differences in soil properties may result from positive feedback effects between biological activity, organic matter decomposition, incorporation of residues into mineral soil through bioturbation, development of soil structure and root growth (Sheriff and Nambiar 1995). Irrespective of the exact reason, the diagnosis of reduced biological activity in the Habsburg soils is in line with the observation that the compost was not incorporated into the soil at Habsburg, but was still separated from the mineral soil below by a welldefined boundary even 7 years after application. In addition, the roots were concentrated in the compost layer, where apparently sufficient nutrients, oxygen and water were available to sustain extraordinarily strong tree growth, which was in contrast to the situation at Messen. Low bioturbation at Habsburg compared to Messen was indicated furthermore by the bulges and ruts that were still present in the skid lanes when the soil profiles were sampled in 2009 and 2010.

In conclusion, our results show that (1) black alders are capable of growing in and penetrating severely compacted soil below skid lanes with their roots and (2) the regeneration of soil structure was significantly accelerated by the planting of black alder trees in parallel with the density of their roots in the soil. Although the regeneration of soil structure was not complete, and much further research is needed to unravel the complex interactions between roots, soil biological activities and soil structure, including rhizobox experiments, the outcomes of our study are very encouraging. There are certain limitations in the use of black alder for the regeneration of compacted forest soils deriving from the demands of this species on soil and climate conditions. Due to its high demand for light and water, it will not work in dense stands and will require a rather humid climate or access to shallow groundwater. However, if adequate site conditions are given, the method has great potential as it is easy and cheap to implement, environmentally friendly and may even provide some economic return, as alder wood can be used as biofuel, for pulp and paper and for other purposes such as artistic and furniture joinery work.

Acknowledgments We are very grateful to Roger Köchli and Marco Walser for their great support during the field works and in the laboratory. The project was funded by the "Fonds zur Förderung der Wald und Holzforschung" of the Federal Office for the Environment (BAFU).

\section{References}

Alakukku L (1996) Persistence of soil compaction due to high axle load traffic. 2. Long-term effects on the properties of finetextured and organic soils. Soil Tillage Res 37:223-238

Alameda D, Villar R (2009) Moderate soil compaction: implications on growth and architecture in seedlings of 17 woody plant species. Soil Tillage Res 103(2):325-331. doi:10.1016/j.still. 2008.10.029

Angers DA, Caron J (1998) Plant-induced changes in soil structure: processes and feedbacks. Biogechemistry 42(1/2):55-72

Apel K (2001) Wandel der Arbeitswelt der Waldarbeiter im Übergang zum 21. Jahrhundert. AFZ/Der Wald 1:14-16

Armstrong W, Armstrong J (2005) Stem photosynthesis not pressurized ventilation is responsible for light-enhanced oxygen supply to submerged roots of alder (Alnus glutinosa). Ann Bot 96(4):591-612. doi:10.1093/aob/mci213

Arvidsson J (1999) Nutrient uptake and growth of barley as affected by soil compaction. Plant Soil 208(1):9-19. doi:10.1023/a: 1004484518652

Bassett IE, Simcock RC, Mitchell ND (2005) Consequences of soil compaction for seedling establishment: implications for natural regeneration and restoration. Austral Ecol 30(8):827-833

Batey T (2009) Soil compaction and soil management-a review. Soil Use Manag 25(4):335-345. doi:10.1111/j.1475-2743.2009. 00236.x

Berli M, Kulli B, Attinger W, Keller M, Leuenberger J, Fluhler H, Springman SM, Schulin R (2004) Compaction of agricultural and forest subsoils by tracked heavy construction machinery. Soil Tillage Res 75(1):37-52. doi:10.1016/s01671987(03)00160-0

Beven K, Germann P (1982) Macropores and water flow in soils. Water Resour Res 18(5):1311-1325. doi:10.1029/ WR018i005p01311

Blake GR, Nelson WW, Allmaras RR (1976) Persistence of subsoil compaction in a mollisol. Soil Sci Soc Am J 40(6):943-948

Boden AG (1982) Bodenkundliche Kartieranleitung, 3rd ed. Schweizerbart'sche Vertragsbuchhandlung (Nägele und Obermiller), Stuttgart

Brais S (2001) Persistence of soil compaction and effects on seedling growth in northwestern Quebec. Soil Sci Soc Am J 65:1263-1271

Brändli BR (2010) Schweizerisches Landesforstinventar. Ergebnisse der dritten Erhebung 2004-2006. Birmensdorf, Eidgenössische Forschungsanstalt für Wald, Schnee und Landschaft WSL. Bundesamt für Umwelt, BAFU, Bern

Capowiez Y, Cadoux S, Bouchand P, Roger-Estrade J, Richard G, Boizard H (2009) Experimental evidence for the role of earthworms in compacted soil regeneration based on field observations and results from a semi-field experiment. Soil Biol Biochem 41(4):711-717. doi:10.1016/j.soilbio.2009.01.006

Carminati A, Vetterlein D, Weller U, Vogel HJ, Oswald SE (2009) When roots lose contact. Vadose Zone J 8(3):805-809. doi:10. 2136/vzj.2008.0147

Claessens H, Oosterbaan A, Savill P, Rondeux J (2010) A review of the characteristics of black alder (Alnus glutinosa (L.) Gaertn.) and their implications for silvicultural practices. Forestry 83(2):163-175

Corns IGW (1988) Compaction by forestry equipment and effects on coniferous seedling growth on 4 soils in the Alberta Foothills. Can J For Res 18(1):75-84

Delage P, Cui YJ, De Laure E (1998) Air flow through an unsaturated compacted silt. In: Proceedings of the 2 nd international conference on unsaturated soils, Beijing, pp 563-568 
Dexter AR (1987) Compression of soil around roots. Plant Soil 97(3):401-406. doi:10.1007/bf02383230

Dickerson BP (1976) Soil compaction after tree-length skidding in Northern Mississippi. Soil Sci Soc Am J 40(6):965-966

Dittert K, Wötzel J, Sattelmacher B (2006) Responses of Alnus glutinosa to anaerobic conditions-mechanisms and rate of oxygen flux into the roots. Plant Biol 8(2):212-223. doi:10.1055/ s-2005-873041

Dorioz JM, Robert M, Chenu C (1993) The role of roots, fungi and bacteria on clay particle organisation-an experimental approach. Geoderma 56(1-4):179-194. doi:10.1016/00167061(93)90109-x

Ellenberg H (1996) Vegetation Mitteleuropas mit den Alpen in ökologischer, dynamischer und historischer Sicht. Ulmer, Stuttgart, Stuttgart

Ellenberg H, Klötzli F (1972) Waldgesellschaften und Waldstandorte der Schweiz. Mitteilungen/Schweizerische Anstalt für das Forstliche Versuchswesen; Band 8, 1972/Heft 4

Eschenbach C, Kappen L (1999) Leaf water relations of black alder [Alnus glutinosa (L.) Gaertn.] growing at neighbouring sites with different water regimes. Trees 14(1):28-38

Franz T (2010) Forstverwaltungssysteme. Norbert Verlag, RemagenOberwinter

Froehlich HA (1979) Soil compaction from logging equipmenteffects on growth of young Ponderosa Pine. J Soil Water Conserv 34(6):276-278

Froehlich HA, Miles DWR, Robbins RW (1985) Soil bulk-density recovery on compacted skid trails in Central Idaho. Soil Sci Soc Am J 49(4):1015-1017

Gaertig T, Hildebrand EE, Schäffer J, Von Wilpert K (2000) Wirkung mechanischer Bodenlockerung auf Bodenbelüftung und Durchwurzelung. AFZ/Der Wald 21:1124-1126

Gameda S, Raghavan GSV, McKyes E, Watson AK, Mehuys G (1994) Long-term effects of a single incidence of high axle load compaction on a clay soil in Quebec. Soil Tillage Res 29(2-3):173-177. doi:10.1016/0167-1987(94)90054-x

Gibbs RJ, Reid JB (1988) A conceptual model of changes in soil structure under different cropping systems. In: Stewart BA (ed) Advances in soil science, vol 8. Springer, New York, pp 123-149

Gill CJ (1975) Ecological significance of adventitious rooting as a response to flooding in woody species, with special reference to Alnus glutinosa (L) Gaertn. Flora 164(1):85-97

Glavac V (1972) Über Höhenwuchsleistung und Wachstumsoptimum der Schwarzerle auf vergleichbaren Standorten in Nord-, Mittelund Südeuropa. Schriftenreihe der Forstlichen Fakultät der Universität Göttingen 45

Greacen EL, Sands R (1980) Compaction of forest soils-a review. Aust J Soil Res 18(2):163-189. doi:10.1071/sr9800163

Håkansson I, Reeder RC (1994) Subsoil compaction by vehicles with high axle load-extent, persistence and crop response. Soil Tillage Res 29(2-3):277-304

Hameberger J (2003) Wie Mechanisierung und Umweltvorsorge die Forstwirtschaft veränderten. LWF Aktuell 39:33-36

Hamza MA, Anderson WK (2005) Soil compaction in cropping systems: a review of the nature, causes and possible solutions. Soil Tillage Res 82(2):121-145

Hildebrand EE (1983) The influence of soil compaction on soil functions on forest sites. Forstwiss Cent bl 102(2):111-125

Howard RF, Singer MJ, Frantz GA (1981) Effects of soil properties, water-content, and compactive effort on the compaction of selected California forest and range soils. Soil Sci Soc Am J 45(2):231-236

Ingold K, Zimmermann W (2011) How and why forest managers adapt to socio-economic changes: a case study analysis in Swiss forest enterprises. For Policy Econ 13(2):97-103. doi:10.1016/j. forpol.2010.06.003

Kemmitt SJ, Wright D, Goulding KWT, Jones DL (2006) pH regulation of carbon and nitrogen dynamics in two agricultural soils. Soil Biol Biochem 38(5):898-911. doi:10.1016/j.soilbio. 2005.08.006

Kooistra MJ, Bouma J, Boersma OH, Jager A (1984) Physical and morphological characterization of undisturbed and disturbed ploughpans in a sandy loam soil. Soil Tillage Res 4(5):405-417

Köstler JN, Brückner E, Bibelriether H (1968) Die Wurzeln der Waldbäume. Verlag Paul Parey, Hamburg u, Berlin

Kreutzer K (1961) Wurzelbildung junger Waldbäume auf Pseudogley. Forstwiss Cent bl 80(11-12):356-392

Labelle ER, Jaeger D (2011) Soil compaction caused by cut-to-length forest operations and possible short-term natural rehabilitation of soil density. Soil Sci Soc Am J 75(6):2314-2329. doi:10.2136/ sssaj.2011.0109

Lowry GL, Brokaw FC, Breeding CHJ (1962) Alder for reforesting coal spoils in Ohio. J For 60:196-199

Materechera SA, Kirby JM, Alston AM, Dexter AR (1994) Modification of soil aggregation by watering regime and roots growing through beds of large aggregates. Plant Soil 160(1):57-66. doi:10.1007/bf00150346

McVean DN (1956) Ecology of Alnus glutinosa (L.) Gaertn. IV. Root system. J Ecol 44(1):218-223

Ouellet G, Lapen DR, Topp E, Sawada M, Edwards M (2008) A heuristic model to predict earthworm biomass in agroecosystems based on selected management and soil properties. Appl Soil Ecol 39(1):35-45. doi:10.1016/j.apsoil.2007.11.003

Page-Dumroese DS, Jurgensen MF, Tiarks AE, Ponder F, Sanchez FG, Fleming RL, Kranabetter JM, Powers RF, Stone DM, Elioff JD, Scott DA (2006) Soil physical property changes at the North American long-term soil productivity study sites: 1 and 5 years after compaction. Can J For Res 36(3):551-564. doi:10.1139/ s05-273

Passioura JB (2002) Soil conditions and plant growth. Plant Cell Environ 25(2):311-318

R Development Core Team (2011) R: a language and environment for statistical computing. R Foundation for Statistical Computing, Vienna

Schäffer B, Attinger W, Schulin R (2007a) Compaction of restored soil by heavy agricultural machinery-soil physical and mechanical aspects. Soil Tillage Res 93(1):28-43

Schäffer B, Eggenschwiler L, Suter B, Vogt L, Buchter B, Pfister H, Schulin R (2007b) Einfluss der Zwischenlagerung auf die anfängliche Entwicklung rekultivierter Oberböden. J Plant Nutr Soil Sci 170:669-681

Schäffer J, Buberl H, von Wilpert K (2012) Deformation damages in forest topsoils - an assessment based on level-I soil monitoring data from Baden-Württemberg (SW Germany). J Plant Nutr Soil Sci 175(1):24-33

Schmidt-Vogt H (1971) Wachstum und Wurzelentwicklung von Schwarzerlen verschiedener Herkunft. Allg Forst Jagdztg 142:149-156

Schoenholtz SH, Van Miegroet H, Burger JA (2000) A review of chemical and physical properties as indicators of forest soil quality: challenges and opportunities. For Ecol Manag 138(1-3):335-356

Schröder P (1989) Aeration of the root-system in Alnus glutinosa L. Gaertn. Ann Sci For 46:S310-S314

Sheriff DW, Nambiar EKS (1995) Effect of subsoil compaction and three densities of simulated root channels in the subsoil on growth, carbon gain and water uptake of Pinus radiata. Aust J Plant Physiol 22(6):1001-1013 
Sinnett D, Poole J, Hutchings TR (2008) A comparison of cultivation techniques for successful tree establishment on compacted soil. Forestry 81(5):663-679. doi:10.1093/forestry/cpn039

Soane BD, Van Ouwerkerk C (1994) Soil compaction problems in world agriculture. Soil compaction in crop production. Elsevier, Amsterdam

Tang AM, Cui YJ, Eslami J, Defossez P (2009) Analysing the form of the confined uniaxial compression curve of various soils. Geoderma 148:282-290

Thorud DB, Frissel SS (1976) Time changes in soil density following compaction under an oak forest. Minnesota Forestry Research Notes, University of Minnesota, St Paul 257

Tracy SR, Black CR, Roberts JA, Mooney SJ (2011) Soil compaction: a review of past and present techniques for investigating effects on root growth. J Sci Food Agric 91(9):1528-1537. doi:10.1002/ jsfa. 4424

Tri BH (1968) Dynamique de la granulation du sols sous prairie. Annuales Agronomique 19:415-439
USDA (1997) Keys to soil taxonomy by the soil survey staff. Soil Cons Serv, US Dept Agr, 7th ed. Pocahontas Press, Blackburg Von Wilpert K, Schäffer J (2006) Ecological effects of soil compaction and initial recovery dynamics: a preliminary study. Eur J For Res 125(2):129-138. doi:10.1007/s10342-005-0108-0

Whalley WR, Dumitru E, Dexter AR (1995) Biological effects of soil compaction. Soil Tillage Res 35(1-2):53-68

WRB IWG (2006) World reference base for soil resources-a framework for international classification, correlation and communication. World Soil Resources Reports 103 International Union of Soil Sciences, ISRIC-World Soil Information and Food and Agriculture Organization of the United Nations, Rome Zimmermann S, Luster J, Blaser P, Walthert L, Lüscher P (2006) Waldböden der Schweiz 3-region Mittelland und Voralpen, vol 3. Waldböden der Schweiz. Hep Verlag, Bern 